\section{Understanding Governance Challenges in Africa}

Harrison Adewale Idowu

Adekunle Ajasin University, Akungba-Akoko, Nigeria

Obafemi Awolowo University, Ile-Ife, Nigeria

\section{Synonyms}

Crises; Government; Leadership; Shortfall

\section{Definitions}

Challenge This refers to a barrier, a draw back to the ability to achieve certain set goals and objectives. It is the difficulty facing the accomplishment of a task.

Governance This refers to the act of policymaking and implementation to drive the affairs of the state. It involves providing political leadership to the people and the country at large.

\section{Introduction}

In Africa, governance remains a major and critical challenge facing the continent. The people have been denied and are continuously being denied good governance over the years. Whereas, the continent has freed itself from the shackles of colonization several decades ago, yet it has not been able to really chart a path for undisputable and functioning governance structure for itself. The potentials for development that decolonization was envisaged to bring has been jeopardized and missed in the face of governance failure. Hence, rather than make significant progress, many African states look worse off when compared to their colonial days. While only a few have made some level of progress, others have retrogressed significantly, raising questions over justification for their independence, when actually they cannot take charge of their affairs and people. The continent seems to have been placed under a curse of governance failure and irresponsible governance.

It is no doubt that governance rules the affairs of the state and set the pace for human and capital development. The circumstance, therefore, that Africa is significantly lagging behind in terms of quality governance explains the resultant lack of human and capital development so visibly rampant on the continent. Challenges like corruption, democratic erosion, insecurity, electoral violence, conflicts and manipulation, and state capture of institutions, among others, continue to ravage the prospects of quality and good governance in Africa. Africans have continued to be governments for themselves, striving to provide for themselves services and public goods which are ordinarily the sole responsibilities of the state. 
Nothing could better describe governance failure. The series of challenges which continue to beset the continent - infrastructural decay, dilapidated schools and hospitals, educational challenges, and increasing crime rates, among others - speak to the high level of governance failure in Africa.

Despite the fact that Africa is blessed with massive mineral and natural resources, with huge population of highly industrious people, the continent continues to languish in developmental challenges, poverty, hunger, and debt (Antonio 2010). The absence of quality governance to coordinate this caliber of population and exploit the abundant resources to drive development has led to conflicts of various dimensions across the continent. Given this governance challenge, natural resources have thus become a curse rather than blessing for Africa, often spiking violent conflicts, most of which have last through several decades and impede development among countries. Glaringly, Africa has continued to struggle with the political and governance institutions and practices that were passed on to it by colonial masters, which completely do not fit into the African system (Afegbua and Adejuwon 2012). These institutions and practices have hence, not been able to resolve the many governance challenges on the continent. Over the years, African post-independent state continue to struggle with the challenges of finding and building the right political and governance institutions and practices that best fit the peculiar challenges on the continent.

How then do we interpret and give meanings to these governance challenges in Africa for clearer understanding of the enormity of these challenges as a first step toward addressing them? This is the concern of this entry - to paint these critical governance challenges vividly and how they reflect and impact on governance in Africa. However, the entry does not claim an exhaustive approach to these issues. The entry thus provides an insight into how corruption, insecurity, democratic erosion, leadership challenge, and state capture of relevant institutions continue to pose serious challenges to governance on the continent. It discusses the interrelatedness of these challenges and governance under performance in Africa.
Understanding the governance challenges in Africa is important as it is the first crucial step toward addressing these challenges and taking them heads on. This is correct to the extent that understanding a problem increases the prospects of finding tenable solution to the problem and vice versa.

Following this introduction, the next section addresses the governance challenges in Africa again these challenges are not exhaustive but are deemed critical among other numerous challenges. The subsequent sections present these challenges systematically, while the final section provides a conclusion for the entry.

\section{Governance Challenges in Africa}

Five critical governance challenges besetting Africa are discussed in the following sections.

\section{Corruption}

Arguably, corruption remains the greatest bane of governance and development in Africa. Corruption spans through every aspects and facets of society in Africa. From followers to the leadership, including public officers, corruption permeates the continent. The gross diversion of public funds by those who have been saddled with the responsibility to govern has left Africa largely underdeveloped. The menace of corruption runs through most government institutions that it has become practically impossible to transact in any public space without having to give bribes in Africa. Politicians who are privileged to get into public offices steal money and export them to be stashed in bank accounts abroad. This has occurred in wantonly and frightening levels, so much so that the natural resources which the continent is so blessed with now amounts to naught. For instance, 22 years after the rule and death of the military dictator General Sani Abacha of Nigeria, the country keeps receiving repatriated billions of US dollars and Euros stashed in bank accounts abroad by the one-time Head of State. This speaks volume of the rate of mass looting of state treasury going on in Africa. Money and resources that could have been deployed for 
socioeconomic, infrastructural, and human capital development have been siphoned into private individual pockets. This has left public roads, hospitals, schools, and other public services in a devastating state in Africa.

Corruption has affected every facets of life in Africa-economic, political, and social - causing a major drawback in these aspects of life. It is with no doubt one of the biggest governance challenge on the continent, as its adverse effect on governance inadvertently impacts on other aspects of society. It has impacted on the well-being of societies, families, and individuals, causing many households to be plunged into hunger and poverty. This is correct to the extent that resources which could have been directed toward sociocapital development of citizens and families end up in the pockets of those in whose hands such resources have been entrusted. For instance, the covid-19 pandemic has further unraveled the awful state of public health facilities in Africa. Many years of corruption and embezzlements of public funds have resulted in the diversion of funds meant for health research institutes and upgrading medical facilities in Africa. The adverse effect of this has been brought to the open by the covid-19 pandemic, which is now revealing more glaringly the devastating state of healthcare system in most parts of the continent.

With respect to corruption in public institutions, most Africans think that corruption is rising fast on the continent, with more than one in four Africans having to give a bribe to access public services like healthcare, Police, and education services (Transparency International 2019). This corruption in government institutions ensures that the poor is continuously deprived unlimited access to public services and are made to spend their meager savings on bribes to access these essential services where available. Corruption has crept into every government institutions from the Police to other institutions. The Police has been found to be the most corrupt government institution across Africa (Transparency International 2019). In fact, the Nigerian Police now gives smaller denomination of the naira (change) to citizens who give them higher denominations as bribes because they have no smaller denominations. They confidently practice this on Nigerian highways in the glare eyes of the public and none has been convicted or dismissed for such act. A show of some confidence that those at the top of the hierarchy are in support of their sharp practices.

Given the spate of corruption in Africa, including its ravaging effects, it has been correctly captioned as the AIDS of democracy on the continent which has continued to destroy the hope and future of many societies (Hope and Chikulo 2000). The greatest contribution and enhancement to corruption in Africa could be explained in the politicization of bureaucracy on the continent. This has allowed a sort of agreement between politicians and bureaucrats to loot the treasury dry. This has continued to advance corruption in Africa. Until bureaucracy is depoliticized in Africa, corruption may continue unabated and consume the continent. In African Parliaments, parliamentarians receive kickbacks to sponsor and pass bills in favor of certain big firms and corporate bodies, including the executive. While they do this, they continue to receive bogus pay from public treasury for which they deliver no significant development to the respective constituencies which they claim to represent. Where and when they ever execute projects in their constituencies, contracts are awarded in the most corrupt manner to the highest bidder of contractors who can give the highest kickback and not necessarily those who can do the job better.

At citizen level, while Africans continue to complain about corrupt politicians and those in public offices (elected or appointed), citizens themselves involve in corrupt practices, cheating one another. In the market places, business owners simply increase prices to catch in on any situation, without any increase in production cost. Transporters hike transport fares even when there is no increment on Premium Motor Spirit (PMS). These are only but a few of such citizen corruption going on, on a large scale in Africa. The engagement in the production of counterfeits to make quick money is on the increase by the day. Counterfeits of consumables are produced without recourse to how this poses threat to the health of fellow 
citizens who may end up consuming them - this is corruption indeed.

Quite undeniably, African politicians and elites have been involved in massive corruption and looting of state treasury, nevertheless, citizens themselves are not spared of the corruption pandemic going on in Africa. This has posed and continue to pose serious challenge to the governance on the continent.

\section{Insecurity}

The increasing spate of acts of insecurity in Africa constitute yet another governance challenge on the continent. Over the years, Africa has continued to deploy huge resources that could have been directed toward socioeconomic development on addressing security challenges. African budgets have seen an increasing rise in security allocations, far higher than what have been allocated to other critical sectors like health, education, and infrastructural development. Boko Haram in the Lake Chad Basin, activities of the Islamic State in West Africa (ISWA), kidnappings, and farmer/ herder clashes in Sudan and Nigeria, proliferation of local wings of Al Qaeda and ISIS, banditry in most parts of the continent, small arms proliferation across Africa, among others, are serious challenges to governance. Besides, as the resources insecurity is currently gulping in Africa, the needed attention that government should give to other critical governance issues is being diverted to address serious security issues capable of tearing the continent apart. Where insecurity thrives, as in Africa currently, development, peace, and stability are jeopardized (Afolabi and Idowu 2019). This explains the lack of significant development, the chaos, and instability ravaging most parts of the continent. For example, the destructive activities of Boko Haram terrorist sect in the Lake Chad Basin have resulted in retarded and distorted economic, social, and political developments, especially in North Eastern region of Nigeria.

The farmer/herder crises ravaging most parts of Sudan, Nigeria, and other parts of Africa constitutes a serious drawback for governance and development. The series of intrastate conflicts going on in Africa is another source of concern for the prospects of good governance on the continent. The ravaging effects of wars and ethnic conflicts in Nigeria, Somalia, Ethiopia, Eritrea, Burundi, Angola, Democratic Republic of Congo (DRC), Sudan, Liberia, Sierra Leone, and Rwanda have ensured stunted socioeconomic and political growth in the countries. While years of civil and ethnic wars may sometimes pass, the devastating effects they leave behind continue to pose threat to good governance. Years of resource commitment are required to rebuild the effect of such wars and insecurity. For economic, social, and political development to be achieved in such society, states must deploy huge and expensive resources to rehabilitate the society. This is often at the expense of resources that could be utilized to provide better life for citizens and improve public services to midwife societal development. It suffices to add that while the world is currently directing all its resources toward containing the Covid-19 pandemic, some African countries are faced with insecurity challenges to deal with alongside the pandemic. This is as terrorist groups and bandits have continued their deadly terror attacks on towns and villages. This diverts both attention and resources from the Covid-19 pandemic which currently demands full scale global attention.

The point must, however, be made that while insecurity negatively impacts governance in Africa, often times, insecurity is a product of governance failure. Whereas most governments have failed to carter for citizen's welfare - education, jobs, and healthcare, among others -, citizens give the excuse of poverty, neglect, and marginalization to get involved in acts that threaten state security. For instance, the Niger Delta militant groups in Nigeria took up arms against the Nigerian state, citing years of government's total neglect as reason for their actions. While the Niger Delta region produces the main stay of the Nigeria's economy - oil -, the region have suffered years of neglect and marginalization over the years. Although politicians steal money accrued from oil exploration from the region, they stash these money abroad and build luxury houses at the nation's capital, leaving the region in abject poverty, gross infrastructural decay, and 
environmental degradation. To attract government's attention, therefore, several militant groups have emerged in the region, causing serious security challenge to date. The Boko Haram, ISWA, and other terrorist groups in Africa have also enjoyed broad and easily enticed membership recruitment, thanks to governance failure on the continent. With so many impoverished and out of school children in Africa, these terror groups find it quite very easy to recruit men against the state that has abandoned them and caused their predicaments.

The autocratic and greedy nature of African leaders has led to conflicts and ethnic crises on the continent. The major conflicts in Sierra Leone, Guinea-Bissau, Liberia, and Cote d'Ivoire over the past decade are traceable to leadership autocracy and greed (Adebajo and Rashid 2004). The antidemocratic practices and ethnic favoritism of African leaders, which often alienate and threaten certain groups and pitch them against one another or to take up arms against the state, constitute a major trigger of insecurity in Africa. Lopsided and highly politicized appointments into public positions, ethnic and tribal favoritism, nepotism, complacency, and strategic marginalization of certain groups have instigated dissatisfied groups to take up arms against the state. Such marginalized groups see it justifiable, therefore, to instigate violence and conflicts against the state. The secessionist groups that such acts of leadership produce often threaten peace, stability, and development. In the end, serious resources are directed toward quailing these crises and putting an end to the destructive actions of such groups. Resources could be deployed more reasonably to other aspects of governance. The point must be made, therefore, that while good governance is critical for peaceful and stable society, so is a stable and peaceful society crucial for good governance.

All the insecurity challenges, whether naturally created or those that arise from governance failure, obviously mitigate sustainable and all-round development in Africa.

\section{Democratic Erosion}

Democracy spread across the African continent in the early 1990 s, albeit there is so much pessimism about the actual practice of democracy across the continent today. This is because many African leaders have continued to hide under the guise of democracy to engage in autocratic practices. This has denied the continent of good governance. Evidences abound across the continent where critical democratic tenets of rule of law, separation of powers, periodic, free and fair election, constitutionalism, and human rights have been subjected to gross abuse. In most parts of Africa, laws are made for the poor and ordinary masses; the rich, politicians, and highly influential personalities continue to breach the law and go scout free. Politicians are especially seen flouting court orders and going against the law in Africa. Also, the executive arm of government continue to lord over the judicial and legislative arms. In most parts, legislature merely projects and executes the whims and caprices of the executive. The judiciary still takes orders from the executive arm in Africa, in strict deferment of separation of powers. For instance, in most parts of the continent, appointment and dismissal of chief justices of countries still rest in the hands of the president who can fire them whenever he deems fit or they refuse to dance to his tune of music.

In Africa, elections still remain largely a veneer which politicians use to keep themselves in power (Idowu and Mimiko 2020). Elections are consistently and grossly manipulated in favor of incumbent presidents just to remain in power. The democratic constitutional term limit in Africa remains constantly under threat. While several attempts have been made to tinker with constitutional term limits on the continent, 15 countries have succeeded in this regard since 2000 (Stremlau 2016: 23). Human rights abuses are still very rampant in Africa; with citizens (especially those belonging to opposition governments) being continuously intimidated and detained in prisons. The Police and other state institutions in Africa have continued to disrespect the rights of citizens in gruesome manner. These have continued to impede good governance on the continent.

The undemocratic attempts and actualization of unconstitutional change in term limits or age limits is a serious governance challenge in Africa. 
In 2015, for instance, Rwanda and Burundi succeeded in tinkering with the constitutional term limit for the office of the president, just to keep the incumbent president in power. In 2018, Uganda succeeded in adjusting the presidential age limit and extended parliamentary term limit. This was a sought of bargain between incumbent President Yoweri Museveni and parliamentarians to allow him contest in the 2020 presidential elections, while also allowing those parliamentarians whose term limit would have reached by the next election to be eligible to contest. Currently, President Alpha Conde of Guinea is lobbying the country's parliament to adjust the constitutional term limit to enable him contest in the next election at the expiration of his second term. Togo, Gabon, Chad, Cameroon, Djibouti, DRC, Sudan, Eritrea, and the Republic of Congo have also gone the way of extension or outright removal of constitutional term limits. The likes of Gambia, Ethiopia, Lesotho, and Morocco never have any term limits in place. Attempts to tinker with presidential term limit have failed elsewhere in Africa Nigeria (2005), Burkina Faso (2014), Niger (2009-2010), and Zambia (2001) (The Conversation 2018). These practices, no doubt, weakens good governance on the continent as they continue to prevent capable hands who can propel Africa out of its numerous challenges from taking over at the helm of affairs, while those who continue to plunge the continent into its current awful state are maintained in power. This has continued to promote and sustain mediocrity in governance, resulting in poor leadership and poor governance.

While popular participation by the people in the decision-making process of the state usually via elections constitute an important aspect of good governance, in Africa, elections are largely not the "people's business" and are not for the people to decide who is elected leaders over them. Indeed, in Africa, those who vote decides nothing, those who count the vote (electoral management bodies largely compromised by incumbents) decides everything. Incumbents and politicians continue to manipulate the electoral process and resort to any acts including violence to come out "victorious" in the process. This hampers good governance on the continent. The democratic erosion or pseudo democracy which has become prominent in Africa, results in poor governance currently demonstrated by poverty, hunger, economic backwardness, corruption, frequent crises, wastefulness, lack of patriotism (Diamond 2002: 6), incompetence, and complacency. Good governance cannot exist where, in fact, those indices which suggest it are missing. The rule of law, constitutionalism, free and fair elections, and respect for human rights are epitome of good governance; where they are lacking, there is governance deficit.

\section{Leadership Challenge}

Leadership and good governance are intrinsically intertwined. One cannot talk of governance without the mention of those at the very helms of governance structure - leaders. Leadership demands high level of charisma and discipline, including intelligence and a foresight. Where the leadership of any country is lacking of these, governance will most certainly encounter some challenges. Most of Africa's leaders lack the leadership charisma capable to provoke good policies which are necessary for good governance. While some of them have claimed all sorts of qualifications to enable them to be eligible to stand for elections, some have simply been "packaged" and presented to the people by those who want to benefit from their leadership. In actual terms, most of them lack the requisite training and experience to provide quality leadership. Hence, most African leaders continue to face the critical question of fitness for leadership. To a very large extent, Africa seems to lack the type of decisive and charismatic leadership needed to propel good governance and socioeconomic and political development currently eluding the continent.

The bulk of Africa's governance challenges has been of leadership failure. Most political leaders on the continent are not innovative to think or work out the solutions to the numerous challenges bequeathing the continent, rather they are much interested in state capture and taking control over state resources. This underscores the willingness of African political leaders to do just about anything to get to power and remain 
there. No clear-cut ideologies among leaders, they are mainly driven by power; as such, African leaders align wherever they can fetch themselves political power and not to any specific ideology. This has resulted in "vision-less" African leaders. In the midst of lack of vision and ideology to make the right policies and take the right decisions to drive good governance, the prospects of development become bleak in Africa. Political power and rule has been largely personalized by African leaders, thus having significant consequences and adverse impacts on robust public policymaking capable to drive good governance and development (Hyden 1992: 23).

African continent continue to lack, to a very large extent, truly patriotic leaders with genuine intentions for the people and the state. The leaders have mostly sought personal gains to the detriment of the people and the state. While the people remain in abject poverty and are denied access to quality life and public services, African political leaders loot the state treasury and make themselves comfortable. They seem to be least concerned about the future of their countries and people, provided they can get luxury life for themselves and their families. This points clearly the lack of patriotism on the part of these leaders. The political will to do good both to the state and the people is grossly inadequate and, in some cases, is out rightly missing among African political leaders.

African leaders have also taken toward autocratic tendencies, presenting themselves as demigods that all state institutions must bow to. Leadership has simply been personalized and deployed for self and personal aggrandizement, rather than for national development. There is, indeed, outright poverty of leadership on the continent, hence everyone tend to behave the way they like. This has been a major governance challenge in Africa. Indeed, Africa needs more Nelson Mandela, Kwame Nkrumah, Obafemi Awolowo, and Julius Nyerere with the right leadership insight to drive good governance and the much desired development.

\section{State Capture of Relevant Institutions}

In Africa, another critical governance challenge has been the one of strategic state capture of relevant institutions that were ordinarily designed to act as watchdogs to the state. African leaders continue to oppress, intimidate, and suppress these relevant institutions critical to force state to implement development driven and progressive ideas and polices. The media and civil society which were supposed to mount pressure on government and criticize its policies that are antipeople and anti-developmental have been pocketed by most African leaders. This creates a situation which has left the continent with a proliferation of governance style and policies that are largely anti-people and lack the requisite rigor to drive development. While some of these institutions have been suppressed, others have simply been bought over by state governments.

Press freedom has been dealt a blow in Africa via the continuous use of imprisonment, pressure, and acts of harassment to suppress independent reporting on the state of governance on the continent (Freedom House 2015). Only a few Africans live in a country where there is free media reporting on government activities and independently playing the watchdog role for effective governance. Also, opposition governments are nonexistent in Africa. Whereas opposition government is another relevant institution expected to put the incumbent government on its toes, in terms of delivering good governance and development, sadly, opposition has been largely silenced in Africa. Incumbent governments continue to harass, intimidate, and suppress opposition groups on the continent. This is grossly inimical to governance and development as the watchdog role of the opposition is eliminated by these acts.

Nongovernmental Organizations (NGOs), democratic groups, civil society groups, and human rights defenders have suffered and continue to suffer harassment and suppression form state governments in Africa. This has resulted in the silence of most of the groups in their course to ensure that the government delivers good governance and development to the people. It is also correct, however, that some African governments have simply bought some of these groups over, 
sometimes creating and funding their own groups. These groups, the ones bought over and those created by the state, do no longer see anything wrong with whatever the government does. Their ability to provide constructive criticism to the government has, thus, been dashed a huge blow. For good governance and development to be achieved in Africa, these relevant institutions must be allowed to play their roles freely and independently.

\section{Conclusion}

This entry has been able to shed light on critical governance challenges in Africa. While the challenges presented in the entry are not exhaustive, they are, however, considered the most delicate and the most disturbing governance challenges which currently confront the continent. If the continent must make significant progress in governance and development, these challenges must be addressed heads on and holistically. By so doing, Africa will be set on the path of greatness again.

\section{Cross-References}

\author{
- Governance Limitations \\ - Leadership Problems \\ - Leadership Shortfall \\ > Poor Governance
}

\section{References}

Adebajo A, Rashid I (2004) West Africa's security challenges: building peace in a troubled region. A project of the International Peace Academy. Lynne Rienner Publishers, Inc. 1800 30th Street, Boulder

Afegbua S, Adejuwon KD (2012) The challenges of leadership and governance in Africa. Int $\mathrm{J}$ Acad Res Bus Soc Sci 2(9): 141-157

Afolabi OS, Idowu HA (2019) Insecurity and the feasibility of democratic governance in West Africa. In: Ani KJ, Eesuola K (eds) International relations and security politics in Africa: essays in honor of Professor Victor Ojakorotu. Academica Press, Washington/London, pp 107-140

Antonio D (2010) The challenges for Africa: a culture of peace, good governance and people-centered development. Asia Pac Rev 8(1):63-74

Diamond L (2002) Elections without democracy: thinking about hybrid regimes. J Democr 13(2):21-35

Freedom House (2015) Five governance challenges in Africa. https://freedomhouse.org/article/5-governancechallenges-africa. Accessed 7 May 2020

Hope KR, Chikulo B (eds) (2000) Corruption and development in Africa. Palgrave Macmillan, Houndmills

Hyden G (1992) Governance and the study of politics. In: Hyden G, Bratton M (eds) Governance and politics in Africa. Lynne Rienner Publishers, Boulder/London

Idowu HA, Mimiko NO (2020) Election management systems and peaceful alternation of power between incumbent and opposition governments in Ghana and Nigeria. Politikon 44:88-111

Stremlau J (2016) Africa's democracies: promises, progress and prospects. Electoral Institute for Sustainable Democracy in Africa, Johannesburg

The Conversation (2018) Presidential term limits: slippery slope back to authoritarianism in Africa. The Conversation, May 17. https://theconversation.com/presidentialterm-limits-slippery-slope-back-to-authoritarianism-inafrica-96796. Accessed 7 May 2020

Transparency International (2019) Citizens speak out about corruption in Africa. Transparency International Survey, July 11. https://www.transparency.org/news/feature/citi zens_speak_out_abput_corruption_in_africa. Accessed 7 May 2020 